\title{
Carbohydrates in the North Sea during spring blooms of Phaeocystis: a specific fingerprint
}

\author{
Ingmar Janse ${ }^{1, *}$, Marion van Rijssel ${ }^{2}$, Jan C. Gottschal ${ }^{1}$, Christiane Lancelot ${ }^{3}$, \\ Winfried W. C. Gieskes ${ }^{2}$
}

Departments of ${ }^{1}$ Microbiology and ${ }^{2}$ Marine Biology, University of Groningen, PO Box 14,9750 AA Haren, The Netherlands ${ }^{3}$ Groupe de Microbiologie des Milieux Aquatiques, Université Libre de Bruxelles, Campus de la Plaine CP 221, Boulevard de Triomphe, B-1060 Bruxelles, Belgium

\begin{abstract}
Regional and temporal variation in the composition of water-soluble carbohydrates from Phaeocystis colonies sampled in the southern North Sea was small during spring 1994, except for a high variability in the contribution of glucose. Glucose is universally present in storage products of microalgae, the relative constancy of the carbohydrate pattern of the other monosaccharides suggests that these are part of the more refractory colony mucus. In all Phaeocystis samples arabinose dominated, followed by xylose (Belgian coast) or galactose and mannose (Dutch coast). Rhamnose, glucuronate and O-methylated sugars were present in lower amounts. The latter, always present in samples containing Phaeocystis, may be typical for North Sea strains. The sugar patterns we report here differ from those presented in the literature concerning Phaeocystis-derived material, and also from the sugar fingerprint in the preceding diatom bloom. The Phaeocystis mucus apparently behaves as particulate matter since it was retained on filters of over $1 \mu \mathrm{m}$. This characteristic together with its refractory nature, typical of 'transparent exopolymer particles' (TEPS), must have consequences for the heterotrophic microbial community in terms of adherence and substrate availability
\end{abstract}

KEY WORDS: Phaeocystis · Mucus · Carbohydrates - Sugars

\section{INTRODUCTION}

The marine prymnesiophyte Phaeocystis has a world-wide distribution (Baumann et al. 1994). In Arctic and Antarctic regions, but also in the North Sea, it is capable of forming massive blooms that often dominate the plankton population (Gieskes \& Kraay 1975, 1977, Lancelot et al. 1994). The taxonomic position and life cycle of Phaeocystis continue to be the subject of studies that started many decades ago (Kornmann 1955, Baumann et al. 1994, Medlin et al. 1994, Rousseau et al. 1994, Vaulot et al. 1994). The alga undergoes phase changes between flagellated single cells and non-motile cells organized in gelatinous colonies. The predominant form during the blooms is the colonial ('palmella') phase.

\footnotetext{
•E-mail: i.janse@biol.rug.nl
}

Colony mucus can contribute up to $90 \%$ to the total Phaeocystis biomass (Rousseau et al. 1990). This cellsurrounding gel is of a polysaccharide nature (Guillard \& Hellebust 1971, Painter 1983). Guillard \& Hellebust (1971) reported the carbohydrates galactose, glucose, mannose, arabinose, xylose, ribose, rhamnose and a hexuronic acid. The contribution of each sugar to the total amount was different in the Surinam and the Massachusetts (USA) strains that they analyzed. In a seawater sample dominated by Phaeocystis, Painter (1983) found a proteoglycan containing hemiester sulphate residues of galacturonic acid, glucosamine, galactose, arabinose, xylose, and rhamnose. The gelling properties of the matrix polysaccharides of Phaeocystis are promoted by salt bridges that involve calcium and magnesium ions that interlink the matrix polysaccharides which, by alcian blue staining, have been shown to contain carboxylated and sulphated groups (van Boekel 1992). 
The physical properties of Phaeocystis colonies change through successive stages of the bloom, from regularly shaped colonies, essentially free of bacteria, to irregular colonies with sticky mucus (Verity et al. 1988, Rousseau et al. 1994, Thingstad \& Billen 1994). Decaying colonies are often abandoned by the cells, leaving empty 'ghosts' that eventually turn into aggregates. It is likely that changes in the physical appearance of the colonies are reflected in their chemical structure and composition. The matrix composition and the possibly related firmness of colonies are of physiological interest since they may affect nutrient uptake and metal speciation (Lubbers et al. 1990), aggregation. and sedimentation (Wassmann et al. 1990), and may even affect resistance to grazing by heterotrophs, ranging from protozoa to copepods (Weisse et al. 1994).

Heterotrophic bacteria interacting with the mucus might alter the matrix properties (Thingstad \& Billen 1994). As a first step towards revealing possible Phaeocystis-bacteria interactions we investigated the carbohydrate composition of Phaeocystis colonies in the course of the spring bloom in the North Sea. Another purpose was to find a possible relationship between structural characteristics of the colony mucus matrix and its biochemical composition.

\section{MATERIAL AND METHODS}

Culturing conditions. Phaeocystis strain BCZ was isolated in 1993 by $\mathrm{V}$ Rousseau at Stn 330 (51 $21^{\circ} \mathrm{N}$, $2^{\circ} 49^{\prime} E_{i}$ Fig. 1). The strain was cultured in 0.51 serum bottles containing $0.4 \mathrm{l}$ seawater $(\mathrm{S}=33 \%$ ) from the

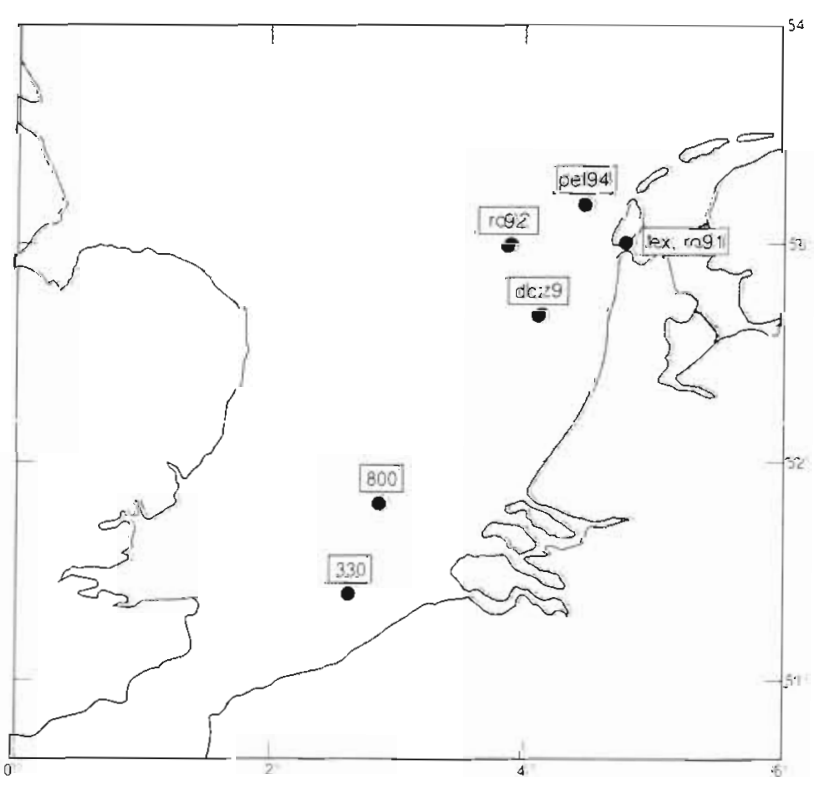

Fig. 1. Sample sites along the North Sea coast
Dogger Bank area that was enriched with 'minor salts', trace elements, and nutrients according to Admiraal \& Werner (1983) and also $0.4 \mathrm{ml}$ of a vitamin solution (Veldhuis \& Admiraal 1987) and additional bicarbonate $\left(0.2 \mathrm{~g} \mathrm{I}^{-1} \mathrm{NaHCO}_{3}\right)$. Bottles were incubated in a culture cabinet $\left(11^{\circ} \mathrm{C}, 14: 10 \mathrm{~L}: \mathrm{D}\right.$ cycle) on a rolling device ( $8 \mathrm{rpm}$ ) at an irradiance of $40 \mathrm{mmol} \mathrm{m} \mathrm{m}^{-2} \mathrm{~s}^{-1}$, measured with a cosine collector.

Sampling. Samples were taken at regular intervals off the Belgian coast (Stn 330) and from the Marsdiep close to Texel, The Netherlands (Fig. 1). Samples were gently taken with a bucket in order to avoid colony disruption; they were then transferred to plastic bottles. In the laboratory, the samples were treated within $5 \mathrm{~h}$ in order to obtain the following fractions:

(1) Total organic matter, i.e. dissolved and particulate, obtained after homogenization of a frozen $\left(-20^{\circ} \mathrm{C}\right)$ and thawed sample.

(2) Dissolved organic matter containing the $<1$ jm fraction obtained by applying gravity filtration, on preashed $\left(4 \mathrm{~h}, 450^{\circ} \mathrm{C}\right) \mathrm{GF} / \mathrm{C}$ glass fibre filters (Whatman). Small volumes $(<10 \mathrm{ml})$ were filtered on relatively large filters $\left(17.3 \mathrm{~cm}^{3}\right)$ to prevent clogging of the filters. With larger volumes the filters were changed regularly (vacuum pressure was never applied).

(3) Material in which colonies of Phaeocystis dominated was usually obtained by gentle filtration of 5 to $20 \mathrm{l}$ over a $250 \mu \mathrm{m}$ mesh net. At some locations (Stns 800, dcz9, ro91, ro92, and pel94) material was obtained by towing a plankton net (100 $\mu \mathrm{m}$ mesh) through a dense Phaeocystis bloom $\left(>10^{6}\right.$ cells $\left.1^{-1}\right)$. Collected material was extracted for $5 \mathrm{~min}$ at $100^{\circ} \mathrm{C}$ after freezing and thawing. Samples were homogenized on a Vortex, centrifuged (29000 $\times g$ for $20 \mathrm{~min}$ ), and dialyzed (Viskin size $18 / 32 "$ Medicell International, pore size $1000 \mathrm{D}$ ) prior to sugar analysis.

For determination of the composition of polysaccharides present in the total seawater fraction, similar homogenization, centrifugation, and dialysis steps were performed prior to concentration using a tangential flow membrane filter (Mini-ultraset, Filtron Technology B.V., The Netherlands) with a pore size of $1 \mathrm{kD}\left(4^{\circ} \mathrm{C}\right)$.

Phytoplankton abundance. The amount of phytoplankton cells was determined by counting of Lugolproscrved samples with an inverted microscope after gentle ultrasonic treatment of the samples to provide an even distribution of cells on the bottom of the counting vessel. Carbon biomass estimates were based on amount and size of cells and colonies. For Phaeocystis the calculation method described by Rousseau et al. (1990) was used, and for diatoms the factor of $0.11 \mathrm{pg} \mathrm{C}$ $\mu \mathrm{m}^{-3}$ recommended by Edler (1979) was used.

Sugar analysis. Sugars present in a sample were analyzed by the modified phenol-sulphuric acid method described by Liu et al. (1973) with glucose as a refer- 
ence. For the determination of the relative sugar composition, samples were methanolyzed $(2.0 \mathrm{M}$ methanolic $\mathrm{HCl}, 24 \mathrm{~h}, 85^{\circ} \mathrm{C}$ ) prior to analysis of the trimethylsilated (N-reacylated) methyl glycosides on a Varian 3600 gas chromatograph equipped with a J\&W DB-1 capillary column (diameter $0.32 \mathrm{~mm}$, length $30 \mathrm{~m}$ ) and a flame ionization detector Identification of sugar derivatives was performed by comparison with known standards; it was confirmed by GLC/MS (Kamerling \& Vliegenthart 1989). Unknown peaks were identified by GLC/MS as O-methylated hexoses and pentoses. These sugars were not available as reference sugars, so the molar ratio was estimated by assuming a degradation factor similar to those of hexoses and pentoses; this will result in an unknown systematic error in the exact amount of these methylated sugars.

\section{RESULTS}

At Stn 330 (Belgian coast) an unexpectedly dense diatom bloom (Rhizosolenia delicatula predominant)


Fig. 2. Stn 330 (Belgian coast), spring 1994. (A) Diatom and Phaeocystis colony biomass. Data from $V$. Rousseau. (B) Total amount of sugars measured in seawater and the $<1 \mu \mathrm{m}$ 'dissolved' fraction, expressed in glucose equivalents was present in spring 1994 (Fig. 2A). Also near Texel the Phaeocystis bloom was preceded by this massive diatom bloom (Fig, 3). At both monitoring stations the phytoplankton community was dominated by Phaeocystis colonies only during a short period of time, from 28 April (Day 118) until late May. The unusually successful development of diatoms over Phaeocystis colonies in 1994 has been attributed by $V$ Rousseau (pers. comm.) to the very rainy weather conditions prevailing in the preceding winter, flushing more riverborne silicate into the North Sea than normal (Schaub \& Gieskes 1991).

Based on microscopic observations, the Phaeocystis species blooming at all sites sampled in this study was identified as Phaeocystis globosa (Baumann et al. 1994). The variation in biomass and cell numbers of Phaeocystis at Stns 330 and tex are presented in Figs. 2A \& 3A (data courtesy of V. Rousseau and G. C. Cadée). Maximum cell numbers at the Stns 330 , tex, ro91, ro92, pel94, 800 and dcz9 were $6.5,18.3,52,3.2$, $1.0,14.7$ and $13.1 \times 10^{6}$ cell $^{-1}$, respectively.
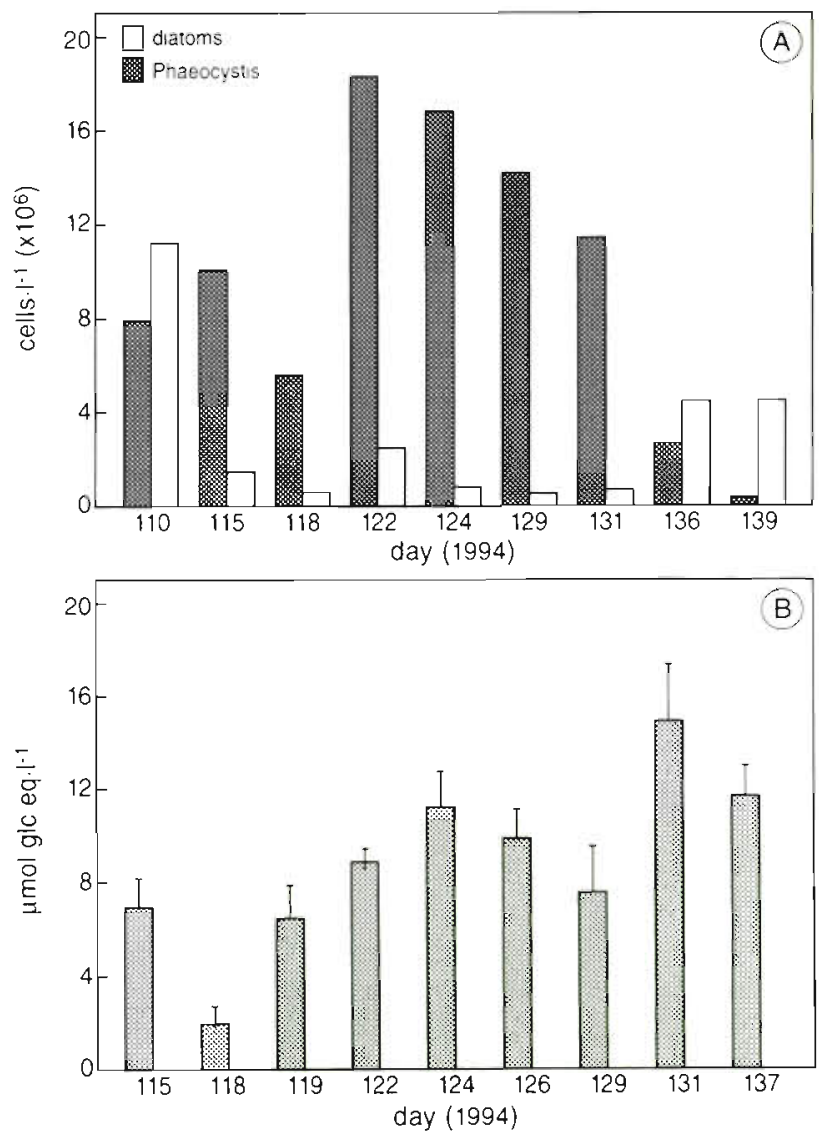

Fig. 3. Stn tex (Texel, Dutch coast), spring 1994. (A) Diatoms and Phaeocystis colonial cells. Data from G. C. Cadée. (B) Total amount of sugars in the water column. All sugars were retained on $\mathrm{GF} / \mathrm{C}$ filters 

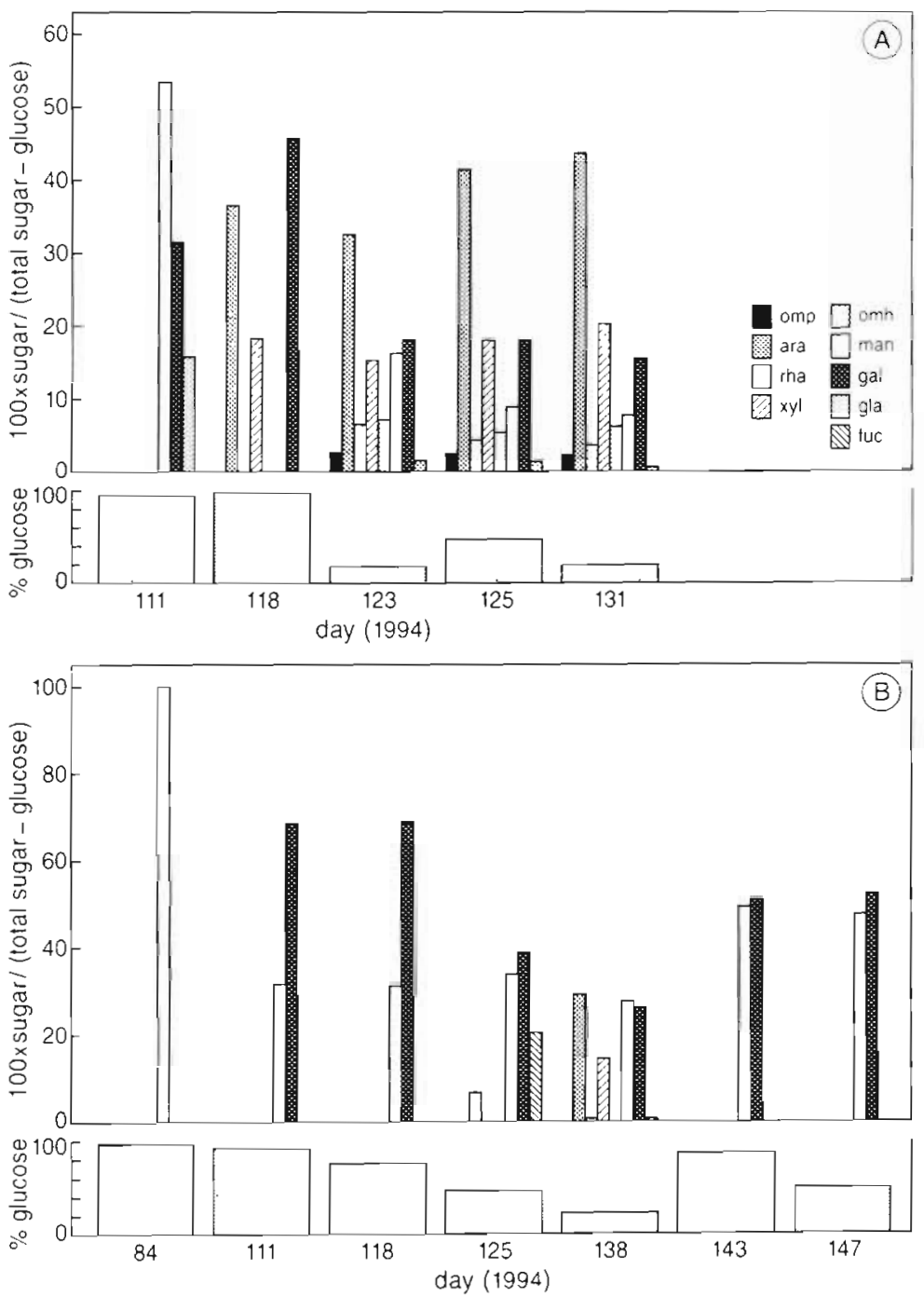

Fig. 4. Stn 330 (Belgian coast). (A) Upper panel: patterns of carbohydrates other than glucose measured in the $>250 \mu \mathrm{m}$ fraction. Lower panel: percentage of glucose to total amount of sugars in the samples. (B) Upper panel: patterns of sugars other than glucose present in the total polysaccharide pool of the water column. Lower panel: percentage of glucose in the samples. Omp: O-methylated pentoses; ara: arabinose; rha: rhamnose xyl: xylose $e_{i}$ mh: O-methylated hexoses; man: mannose; gal: galactose gla: glucuronic acid; fuc: fucose

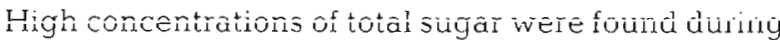
the spring phytoplankton growth phase, i.e. 0.7 to $7.5 \mathrm{mmol} \mathrm{m}^{-3}$ glucose equivalents ( 50 to $540 \mathrm{mg} \mathrm{C} \mathrm{m}^{-3}$ ) at the Belgian reference station (330). One peak coincided with the diatom bloom of Rhizosolenia delicatula (Day 111) and one with the Phaeocystis bloom (Days 131 and 138 ; Fig. 2A). At Stns 800 and dcz9, 11.6 and $6.1 \mathrm{mmol} \mathrm{m}^{-3}$ were found, of which 100 and $89 \%$, respectively, were in the fraction retained by GF/C filters. There was a notable shift from the sugars present predominantly in the 'dissolved' fraction, when the diatom was blooming, to the 'particulate' fraction ( $>1 \mu \mathrm{m}$ ), i.e. total minus 'dissolved' when Phaeocystis became dominant (Fig. 2). Near Texel, all sugars were present in the $>1 \mu \mathrm{m}$ fraction at concentrations varying between 1.9 and $14.9 \mathrm{mmol} \mathrm{m}^{-3}$ glucose equivalents 137 to $1070 \mathrm{mg} \mathrm{C} \mathrm{m}^{-3}$; Fig. 3). The changes in the amounts of sugars in the water column corresponded to the changes observed in phytoplankton biomass (Fig. 3).

The Phaeocystis colony fractions that were obtained on a $250 \mu \mathrm{m}$ mesh filter (or $100 \mu \mathrm{m}$ in case of stations only sampled once) formed a green and viscous layer. The water-soluble carbohydrates that were extracted from this layer contained arabinose, rhamnose, xylose, mannose, galactose, glurose, and glucuronate as well as unidentified O-methylated pentoses and hexoses and traces of ribose (Figs. 4 to 6 ). $\mathrm{N}$-acetyl-glucosamine was not found in these $>250 \mu \mathrm{m}$ samples, indicating that the colony fractions were essentially free of chitin-containing plankton such as copepods.

The diatom bloom sugar pattern (fraction $>250 \mu \mathrm{m}$; analyzed on Days 111 and 118 at Stn 330) differed considerably from that of the Phaeocystis bloom that followed. Only mannose, galactose and relatively large amounts of glucose (385 and 165 times the total amount of other sugars) were present; O-methylated sugars, always found during the Phaeocystis bloom, were lacking during the diatom bloom (Fig. 4A).

Glucose was also the dominant sugar in the total polycarbohydrate pool present in seawater (Fig. $4 \mathrm{~B}$ ), except for the period of the Phaeocystis bloom. At that time (Days 125 and 138) a number of sugars also found in the colony fraction (Fig. 4A) became predominant, which suggests that Phaeocystis contributed most to the polysaccharide pool.

Thle Filatecysiis bioun di Sin tex showed, apart from variable amounts of glucose, a rather constant pattern for the sugars in the $>250 \mu \mathrm{m}$ colony fraction (Fig. 5). The glucuronic acid content seemed to increase slightly over time while mannose decreased. The anomalous pattern on Day 118 was possibly caused by aggregates of the waning Rhizosolenia delicatula bloom that were caught in the $>250 \mu \mathrm{m}$ fraction.

The composition of non-glucose sugars in colony fractions of Phaeocystis sampled in 1994 at different locations were compared (Fig. 6). Arabinose was pre- 
Fig. 5. Stn tex (Texel, Dutch coast). Upper panel: patterns of carbohydrates other than glucose measured in the $>250 \mu \mathrm{m}$ fraction. Lower panel: percentage of glucose in the total amount of sugars in the samples. Abbreviations as in Fig. 4.

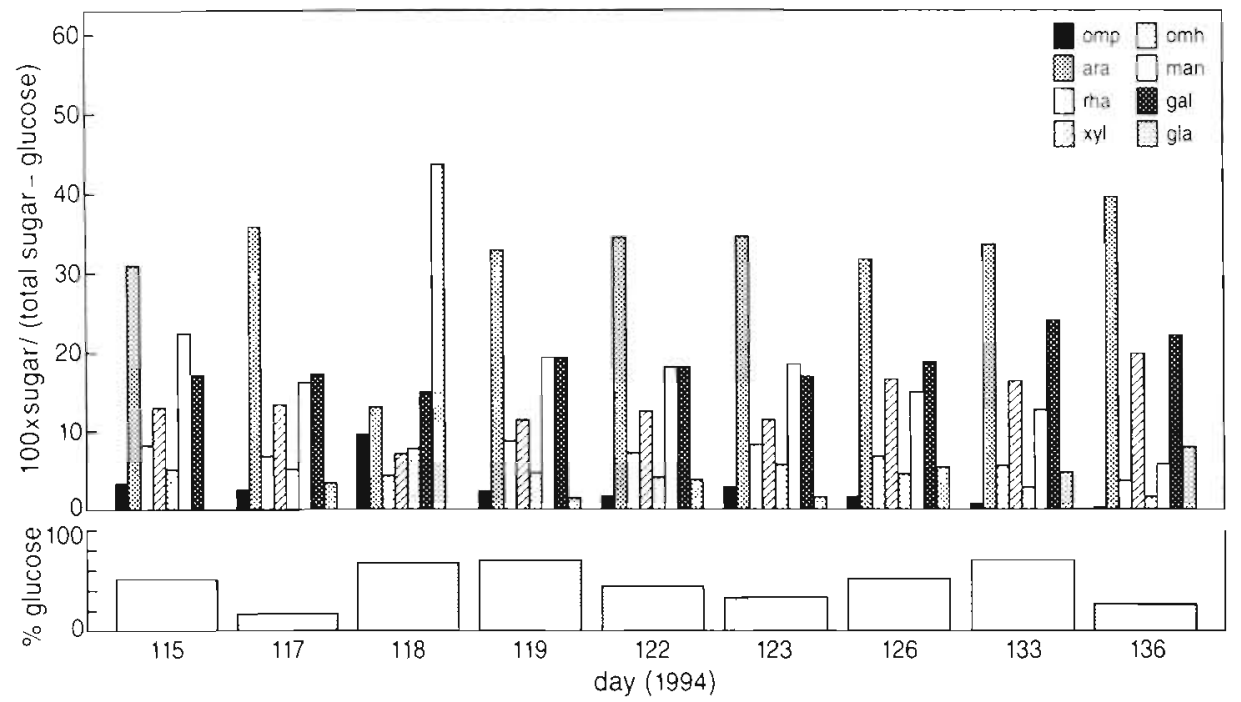

Fig. 6. Comparison of the carbohydrate patterns in different samples collected along the North Sea coast (stations as in Fig. 1). Glucose left out for reasons explained in the text. Abbreviations as in Fig. 3; lab: laboratory

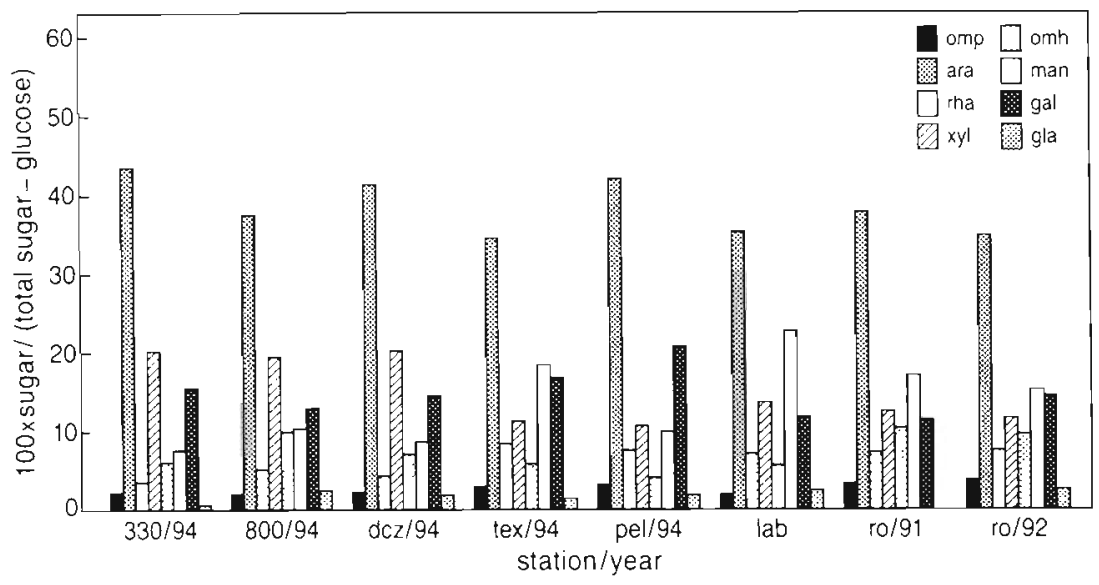

dominant in all these fingerprints; the second most predominant sugar in the Belgian samples was xylose, of which the relative contribution to the total sugar amount decreased northward, while the relative amounts of galactose and mannose increased such that they became the second most predominant sugars in the Dutch samples. The O-methylated sugars were present in all Phaeocystis-containing samples, making up approximately $10 \%$ of the total amount of sugars (glucose not included). The samples ro91 and ro92, although taken in 1991 and 1992, resembled pel94 and tex94 taken in the same area. The laboratory culture of a strain isolated from Stn 330 (Belgian coast) in 1993 but cultured in water from the Dogger Bank (central North Sea) also resembled the Dutch fingerprints.

\section{DISCUSSION}

The sugar composition of the Phaeocystis colonies fraction revealed a complex fingerprint. Apart from the highly variable amounts of glucose, the sugar pattern appeared to be similar along the entire continental North Sea coast, but it was completely different from those reported for Phaeocystis strains originating from the English Channel (Thingstad \& Billen 1994), Surinam and Massachusetts (Guillard \& Hellebust 1971), as well as from the diatom bloom preceding the Phaeocystis bloom (Fig. 4). Samples taken in the North Sea during the Phaeocystis bloom contained arabinose as the most abundant sugar, not mannose as reported by Guillard \& Hellebust (1971). Furthermore, only traces of ribose and fucose were found in our samples. Instead, we identified O-methylated pentoses and hexoses in all our Phaeocystis-containing samples, including a laboratory culture originally isolated from Belgian coastal waters. These methylated sugars may be indicative of the Phaeocystis strains in the North Sea. The sugar pattern of the Belgian Phaeocystis samples is similar to that found by Haug et al. (1973) in a phytoplankton sample from the Trondheimsfjord on 30 March 1971, of which $63 \%$ of the cells was Phaeocys- 
tis, except that the O-methylated sugars were not reported

Despite the overall similarity of the fingerprints along the continental North Sea coast, some regional differences could be identified. In the Belgian samples, arabinose was twice as abundant as xylose and galactose, while in the Dutch area, mannose and galactose were most abundant, next to arabinose. Such local variability may reflect the presence of different strains. Cadée (1991) has suggested that regional blooms are inoculated by just a few colonies wintering in the area. This could be the mechanism by which local strains can develop. Strain differences in genome size and pigment contents have recently been reported for North Sea and English Channel isolates (Vaulot et al. 1994). Carbohydrate fingerprint differences might also be induced by environmental conditions (such as nutrient availability); an indication of this is the fingerprint of the strain isolated from the Belgian coast cultivated in water from the Dogger Bank area (central North Sea) which resembled the Dutch fingerprints

The relative amounts of glucose were highly variable for the different sugar patterns, ranging from 0.2 to 380 times the amount of the other sugars. There are 3 possible explanations for this. Firstly, glucose polymers (glycogen, starch and laminaran) are universally produced as storage polymers by algae (Painter 1983). In fact, Phaeocystis produces a glucan as reserve polymer (Janse et al. 1996). The amount of glucose reserve polymers produced by algae depends highly on the environmental conditions (light and nutrients; Cuhel et al. 1984). Secondly, a contamination of the Phaeocystis colony fraction with other algae can cause a relatively high contribution of glucose to the sugar pool. Thirdly, the consumption of storage glucans can be expected to be rapid when they are consumed by bacteria that are adapted to this energy source. The amount of $\beta$-glucosidase at Stn 330 followed the total phytoplankton biomass development, not the seasonal pattern of any single species (S. Becquevort pers. comm.). Because processes that influence the glucose pool are not Phaeocystis-specific, glucose has been omitted from the comparison of sugar patterns here.

Thie relative anuunits of suyars other than giucose present in Phaeocystis polymers were rather constant in the North Sea area. This suggests that these sugars are part of a structural rather than a storage polymer. needed to form the colony matrix. A structural polymer in Phaeocystis together with a storage glucan (Janse et al. 1996). resembles the situation in diatoms in which an acid-extractable storage glucan is commonly found in addition to more complex structural polymers (Haug \& Myklestad 1976, Brockmann 1982, Hoagland et al. 1993).
The dramatic change of the colony shape during a bloom reported by Verity et al. (1988) and Rousseau et al. (1994) is not reflected in the sugar composition, which remained rather constant. Also, similar sugar fingerprints were found at the Stns 800 and dcz9, where healthy and decaying colonies dominated, respectively (V. Rousseau pers. comm.). Changes in colony firmness may depend on alterations in the amount of negatively charged carboxyl and sulphate groups (van Boekel 1992) or changes in polymer chain length and branching rather than on sugar composition per se.

The concentration of total sugars found during the Phaeocystis bloom is well within the range of 5 to $25 \mathrm{mmol} \mathrm{\textrm {m } ^ { - 3 }}$ glucose equivalents found earlier by Eberlein et al. (1985). Although Phaeocystis is known to be capable of high excretion rates of sugars (Guillard \& Hellebust 1971, Lancelot \& Mathot 1985, Veldhuis \& Admiraal 1985) all carbohydrates were retained upon GF/C filters regardless of the state of the bloom that was sampled. In contrast, most of the carbohydrates present during the preceding diatom bloom passed these filters, except at the very beginning of the bloom when they were apparently associated with the cells. The reason for the different behavior of the carbohydrates produced by the diatoms and Phaeocystis probably lies in the production of matrix polysaccharides, which is so characteristic for Phaeocystis.

The constant sugar composition of this gel-forming colloidal material throughout the bloom may be indicative of its degradation-resistant nature, which results in a relatively long residence time. The result could be the formation of particles large enough to be retained on the filters, thus resembling the transparent exopolymer particles (TEPs) reported by Alldredge et al. (1993). The absence of dissolved sugars during and at the end of the Phaeocystis bloom can be explained by scavenging of dissolved organic matter by such particles (Decho 1990). Since bacteria have been shown to adhere to TEPs (Alldredge et al. 1993) and because the substrates available to the microbial loop are concentrated in these microenvironments (Azam \& Smith 1991), the observation of a high concentration of TEPlike polysaccharides during Phaeocystis blooms in the ivorth Sea suggests an important role of this mucus producing alga in the microbial loop.

Acknowledgements. We thank P. van der Culik, V. Rousseau and R. Osinga for help in sampling, G. C. Cadée and V. Rousseau for biomass estimations, and Dr G. Gerwig (University of Utrecht, Bijvoet Centre) who performed the GC/MS measurements. Prof J. P. Kamerling is acknowledged for access to the facilities in Utrecht. This work was supported by EC contract EV5V-CT94-0511, and by the Centre of Ecological and Evolutionary Studies (CEES) of the University of Groningen, The Netherlands. 


\section{LITERATURE CITED}

Admiraal W, Werner D (1983) Utılization of limiting concentrations of ortho-phosphate and production of extracellular organic phosphates in cultures of marine diatoms. J Plankton Res 5:495-513

Alldredge $A L$, Passow U, Logan BE (1993) The abundance and significance of a class of large, transparent organic particles in the ocean. Deep Sea Res 40:1131-1140

Azam F, Smith DC (1991) Bacterial influence on the variability in the ocean's biochemical state: a mechanistic view. In: Demers $\mathrm{S}$ (ed) Particle analysis in oceanography. NATO ASI Ser, Vol G27. Springer-Verlag, Berlin, p 213-236

Baumann MEM, Lancelot C, Brandini FP, Sakshaug E, John DM (1994) The taxonomic identity of the cosmopolitan prymnesiophyte Phaeocystis; a morphological and ecophysiological approach. J Mar Sys 5:5-22

Brockmann U (1982) Monosaccharide composition of acidhydrolyzable carbohydrates in particulate matter during a plankton bloom. Limnol Oceanogr 27:770-776

Cadée GC (1991) Phaeocystis colonies wintering in the water column? Neth J Sea Res 28:227-230

Cuhel RL, Ortner PB, Lean DRS (1984) Night synthesis of protein by algae. Limnol Oceanogr 29:731-744

Decho AW (1990) Microbial exopolymer secretions in ocean environments: their role(s) in food webs and marine processes. Oceanogr Mar Biol A Rev 28:73-153

Eberlein K, Leal MT, Hammer KD. Hickel W (1985) Dissolved organic substances during a Phaeocystis pouchetii bloom in the German Bight (North Sea). Mar Biol 89:311-316

Edler L (1979) Recommendations for marine biological studies in the Baltic sea. Phytoplankton and chlorophyll. Baltic Mar Biol Publ 5, Lund University, p 1-38

Gieskes WWC, Kraay GW (1975) The phytoplankton spring bloom in Dutch coastal waters of the North Sea. Neth $J$ Sea Res 9:166-196

Gieskes WWC, Kraay GW (1977) Primary production and consumption of organic matter in the southern North Sea during the spring bloom of 1975. Neth J Sea Res 11:146-167

Guillard RRL, Hellebust JA (1971) Growth and the production of extracellular substances by two strains of Phaeocystis pouchetii. J Phycol 7:330-338

Haug A, Myklestad S (1976) Polysaccharides of marine diatoms with special reference to Chaetoceros species. Mar Biol 34:217-222

Haug A, Myklestad S, Sakshaug E (1973) Studies on the phytoplankton ecology of the Trondheimsfjord. 1. The chemical composition of phytoplankton populations. J Exp Mar Biol Ecol 11:15-26

Hoagland KD, Rosowski JR, Gretz MR, Roemer SC (1993) Diatom extracellular polymeric substances: function, fine structure, chemistry, and physiology. J Phycol 29:537-566

Janse I, van Rijssel M, van Hal PJ, Gerwig GJ, Gottschall JC, Prins RA (1996) The storage glucan of Pheocystis globosa (Prymnesiophyceae) cells. J Phycol 32(3):in press

Kamerling JP, Vliegenthart JFG (1989) Mass spectrometry. In: Lawson AM (ed) Clinical biochemistry - principles, methods, applications, Vol 1, Mass spectrometry. Walter de Gruyter, Berlin, p 175-263

Kornmann P (1955) Beobachtungen an Phaeocystis-Kulturen. Helgoländer Wiss Meeresunters 5:218-233

Responsible Subject Editor: F. Thingstad, Bergen, Norway
Lancelot C, Mathot S (1985) Biochemical fractionation of primary production by phytoplankton in Belglan coastal waters during short- and long-term incubations with ${ }^{14} \mathrm{C}$ bicarbonate. II. Phaeocystis pouchetii colonial population. Mar Biol 86:227-232

Lancelot C, Wassmann P, Barth H (1994) Ecology of Phaeocystis-dominated ecosystems. J Mar Sys 5:1-4

Liu D, Wong PTS, Dutka BJ (1973) Determination of carbohydrate in lake sediment by a modified phenol-sulfuric acid method. Water Res 7:741-746

Lubbers GW, Gieskes WWC, del Castilho P, Salomons W, Bril J (1990) Manganese accumulation in the high $\mathrm{pH}$ microenvironment of Phaeocystis sp. (Haptophyceae) colonies from the North Sea. Mar Ecol Prog Ser 59: $285-293$

Medlin LK, Lange M, Baumann MEM (1994) Genetic differentiation among three colony-forming species of Phaeocystis: further evidence for the phylogeny of the Prymnesiophyta. Phycologia 33:199-212

Painter TJ (1983) Algal polysaccharides. In: Aspinall GO (ed) The polysaccharides, Vol 2. Academic Press, New York, p 96-285

Rousseau V, Mathot S, Lancelot C (1990) Calculating carbon biomass of Phaeocystis sp. from microscopic observations. Mar Biol 107:305-314

Rousseau V, Vaulot D, Casotti R, Cariou V, Lenz J, Gunkel J, Baumann MEM (1994) The life cycle of Phaeocystis (Prymnesiophyceae): evidence and hypotheses. J Mar Sys 5:23-29

Schaub BEM, Gieskes WWC (1991) Eutrophication of the North Sea: the relation between Rhine river discharge and chlorophyll-a concentration in Dutch coastal waters. In: Elliot M, Ducrotoy JP (eds) Estuaries and coasts: spatial and temporal intercomparisons. Olsen and Olsen, Fredensborg, p 85-90

Thingstad F, Billen G (1994) Microbial degradation of Phaeocystis material in the water column. J Mar Sys 5:55-65

Van Boekel WHM (1992) Phaeocystis colony mucus components and the importance of calcium ions for colony stability. Mar Ecol Prog Ser 87:301-350

Vaulot D, Birrien JB, Marie D, Casotti R, Veldhuis MJJW, Kraay GW, Chrétiennot-Dinet MJ (1994) Morphology, ploidy, pigment composition, and genome size of cultured strains of Phaeocystis (Prymnesiophyceae). J Phycol 30: $1022-1035$

Veldhuis MJW, Admiraal W (1985) Transfer of photosynthetic products in gelatinous colonies of Phaeocystis pouchetii (haptophyceae) and its effect on the measurement of excretion rate. Mar Ecol Prog Ser 26:301-304

Veldhuis MJW, Admiraal W (1987) Influence of phosphate depletion on the growth and colony formation of Phaeocystis pouchetii. Mar Biol 95:47-54

Verity PG, Villareal TA, Smayda TJ (1988) Ecological investigations of blooms of colonial Phaeocystis pouchetti- I. Abundance, biochemical composition, and metabolic rates. J Plankton Res 10:219-248

Wassmann P, Vernet M, Mitchell BG, Rey F (1990) Mass sedimentation of Phaeocystis pouchetii in the Barents Sea. Mar Ecol Prog Ser 66:183-195

Weisse T, Tande K, Verity P, Hansen F, Gieskes W (1994) The trophic significance of Phaeocystis blooms. J Mar Sys 5 $67-79$

Manuscript first received: September 10, 1995

Revised version accepted: November 20, 1995 